\title{
THIRTY YEARS OF GENDER DIFFERENCES IN SELF-ASSESSED HEALTH: THE CASE OF SLOVENIA TRIDESET LET RAZLIK V SAMOOCENAH ZDRAVJA MED SPOLOMA: PRIMER SLOVENIJE
} Brina Malnar ${ }^{1}$, Mitja Hafner-Fink, 1

Prispelo: 11. 10. 2012 - Sprejeto: 1. 2. 2013

Original scientific article UDC 316.334:614

\begin{abstract}
Background: This article explores gender trends in self-rated health in Slovenia over the period of thirty years. The main research goals are to examine the associations between gender, social class and health, establish the extent that the patterns of subjective health converge with those in other countries and identify the most vulnerable health groups.

Methods: The study is based on six waves of the Slovenian Public Opinion survey carried out between 1981 and 2012 on representative samples of the adult Slovenian population. The main dependent variables are the respondent's self-assessed health and three indicators of psychosomatic health - experiences of insomnia, irregular heartbeat and anxiety. The main independent variables are gender and socio-economic status. The relationship between them was examined using Chi-square tests.

Results: The 30 year trend is consistent with prior studies, which found that women report poorer self-assessed health than men. In Slovenia, this gender gap was observed in both social classes, but was more pronounced for women in the lower educated category. The higher prevalence of stress symptoms among women supports the theory of chronic exhaustion resulting from the dual-role strain.

Conclusions: In Slovenia the welfare state was able to buffer the adverse effects of increased economic stresses to a significant extent after 1991, resulting in favourable health outcomes for both genders. Dismantling these arrangements may result in short-term financial gains but is likely to trigger long-lasting negative consequences for public health, especially in the case of vulnerable groups such as women.
\end{abstract}

Key words: public opinion, self-rated health, gender, social inequality, health policy

Izvirni znanstveni članek UDC 316.334:614

\section{Izvleček}

Uvod: Članek obravnava smernice samoocen zdravja po spolu v Sloveniji za obdobje 30 let. Glavni raziskovalni cilj je proučiti povezavo med spolom, družbenim razredom in zdravjem, ugotoviti, $v$ kakšnem obsegu so vzorci samoocen zdravja skladni s tistimi $v$ drugih državah in razpoznati zdravstveno najranljivejše družbene skupine.

Metode: Študija temelji na šestih anketnih meritvah raziskave Slovensko javno mnenje, ki so bile izvedene v obdobju 1981 in 2012 na reprezentativnih vzorcih odraslega prebivalstva Slovenije. Poglavitne odvisne spremenljivke so anketirančeva samoocena zdravja in trije kazalniki psihosomatskega zdravja - nespečnost, razbijanje srca in nemir. Poglavitni neodvisni spremenljivki pa sta spol in socialno-ekonomski položaj. Zvezo med njima smo ugotavljali s hi-kvadrat testom statistične značilnosti.

Rezultati: 30-letni trend je skladen s predhodnimi študijami, ki ugotavljajo, da ženske slabše ocenjujejo svoje zdravje kot moški. V Sloveniji je razlika med spoloma opazna v obeh družbenih razredih, a je precej izrazitejša pri ženskah $v$ nižji izobrazbeni kategoriji. Večja prisotnost simptomov stresa pri ženskah potrjuje teorijo kronične utrujenosti kot posledice pritiska različnih družbenih vlog. 
Zaključek: V Sloveniji je socialna država po letu 1991 uspela omiliti negativne posledice povečanega ekonomskega stresa, kar se je odrazilo v ugodnih zdravstvenih smernicah pri obeh spolih. Razgradnja teh mehanizmov bi lahko prinesla kratkoročne finančne prihranke, obenem pa bi zelo verjetno imela dolgotrajne negativne posledice za zdravje prebivalstva, zlasti pri ranljivih skupinah, med katerimi so tudi ženske.

Ključne besede: javno mnenje, samoocena zdravja, spol, družbena neenakost, zdravstvena politika

\section{INTRODUCTION}

In virtually every society there is the paradox that women have a longer life expectancy than men, but report higher levels of illness and worse perceived health $(1,2)$. There are several explanations for this, one of them being the theory of social norms. It assumes that women are socialized into over-reporting illness and men into underreporting it. According to work within the Parsonian tradition, women take on the sick role more easily, as it is seen as more socially and culturally acceptable for them to be ill and seek professional help. While women consistently report excess in 'symptoms' such as tiredness, headaches, musculoskeletal problems and chronic pain, men tend to overrate their health, concealing their health problems behind the 'tough man' stereotype $(3,4,6)$. These authors basically suggested that female excessive morbidity is, at least in part, socially constructed.

The lifestyle theory offers another explanation. It comes from the normative background as well, but sees gender differences in health as real and sustained by culturally produced differences in behaviour. It argues that certain life-style habits such as alcohol consumption, smoking and risk-taking are among the causes of the lower life expectancy for men $(2,7)$. The life-style aspect became central in explaining the situation in Eastern Europe during the first decade of transition, when the former communist countries experienced dramatic transformations of their economic, political and social systems, resulting in a sharp decline in economic performance and a collapse in the demand for labour (8). The development seemed to affect eastern European males in particular, making the female advantage in mortality in Eastern Europe often much greater in comparison with western European countries. For example, between 1987 and 1995 the sex difference in LE in Russia increased from 9 to 14 years $(1,9)$.

On the other hand, there are those who maintain that excessive focus on life expectancy comparisons is mistaken and that the quality as well as quantity of life should be taken into account. These scholars are mainly concerned with the fact that despite living longer, women report more 'malaise' or psychosocial symptoms at all ages than men (6). When talking about the gendered health quality of life, the dual role strain seems to become the central issue. There are contrasting views on the significance of multiple roles for women's health. Some argue that having multiple rewarding roles is health promoting, because employment and marriage may substitute for each other as sources of income, health insurance and social support. Others claim that multiple roles have no relevance, or may result in health-damaging role strain $(3,10)$. There is evidence that confining women to the housewife role to relieve them of the double burden does not produce favourable health effects, because social isolation and the denial of self involved in tending other people's needs increasingly has negative mental health effects (6) (11). However, evidence also suggests that for women engaged in both home and paid work, the latter is usually the source of considerable stress and that the symptoms of dual role strain are chronic tiredness and exhaustion, found excessively in women $(4,5)$.

The dual-role strain illustrates the dimension of women's socio-economic status. Studies have shown that women of the non-manual social class have more resources for facing domestic work. High income enables paid help with domestic tasks and childcare to relieve working women of some of the overload (12). This is merely one aspect of how socio-economic differences are entangled with gender differences in health, which is why gender, as a determinant of the health of both men and women, are usually considered in interaction with other inequality axes (2). Work and education are the leading edge of the increased inequalities between women, and while we may be witnessing emerging patterns of equality between some men and some women, this is accompanied by intensified forms of inequality between women and men (10). The existence of within-gender class differences is supported by a large amount of empirical evidence. The invariable pattern, through time and between societies, is one in which men and women in higher socio-economic groups enjoy better health across longer lives than those from lower socio-economic groups. Like men, a higher socioeconomic status protects women from the risk of ill health, while a lower socio-economic status increases their chances of disease (13). Similar findings were 
reported for Eastern Europe where women of a lower social status have suffered disproportionately from the transition to a market economy, confirming fears that the process of marketization would be particularly harmful to vulnerable social groups (9). The effect of class differences in health is very hard to overcome and is likely to persist throughout life. In the UK, for instance, health inequalities according to class are very striking among older men and women and indicate the resilience of the social classes during working life in influencing health into a very old age (14).

Coming from these well-established facts, the aim of this article is to explore the case of Slovenia in crosstime perspective to examine the association between gender, social class and self-rated health during a 30 year period, establish the extent that the patterns of subjective health converge with those outlined for other countries and identify the most vulnerable health groups. Based on the existing body of evidence, we can expect that women will report poorer self-rated health and that there will be notable socio-economic differences within the gender groups.

\section{METHODS}

The study design is a series of cross-sectional studies in time based on representative samples of the adult general population in Slovenia, collected using the face-to-face interview method. The main data source is the Slovenian public opinion survey, housed by the Public opinion and mass communications research centre at the Faculty of Social Sciences, University of Ljubljana. First fielded in 1968, it is the only social survey in Slovenia that began its measurement cycle several decades ago. In the time period between 1981 and 2011, six waves were carried out including identical measures of self-rated health, using representative samples of the adult Slovenian population (18 years and over with no upper age limit): $1981(\mathrm{~N}=2100)$, $1989(\mathrm{~N}=2093), 1994(\mathrm{~N}=1037), 2001 \quad(\mathrm{~N}=1093)$, $2007(\mathrm{~N}=1010)$ and $2011(\mathrm{~N}=1079) .2007$ has limited comparability with other years due to the untypical questionnaire context (15) and was only used in cohort analysis. To measure the attitudes towards the provision of health care by the government, we used the following Slovenian public opinion survey datasets 1989 ( $\mathrm{N}=2040), 1995$ ( $\mathrm{N}=1008), 1997$ ( $\mathrm{N}=1005), 2000$ $(\mathrm{N}=1097), 2006(\mathrm{~N}=1003)$ and $2012(\mathrm{~N}=1026)$.

The first dependant variable in our study is the respondent's self-rated health. The exact question wording was as follows: 'How is your health in general?
Would you say it is ... 1-excellent, 2 - very good, 3 good, 4 - bad, 5-very bad. In Figures 1, 2 and 3, 'good self-assessed health' stands for the sum of 'excellent' and 'very good'. When examining the dynamic of self-assessed health through life (Figure 3), we used cohort analysis. We observed men and women who were between 31 and 43 years of age in 1981 at two more points in time, the last one being 25 years later when their age was between 56 and 68. Because the Slovenian public opinion survey is not a panel survey, the results are not based on the same individuals, but on three probability samples from the respective cohort. We used three additional dependent variables, i.e. three indicators of psychological stress: experiences of insomnia, irregular heartbeat and feelings of anxiety. These lay and holistic self-assessments have proved a very efficient measure of an individual's health in numerous surveys so far and capture the full array of illnesses in a person (17). From the latter three, we created an index by counting their prevalence across every respondent. Its lowest value was 0 for respondents who did not report any of the three symptoms occurring regularly, and the highest value was 3 for those respondents who reported experiencing all three symptoms on a regular basis. The datasets we used in this case come from four time points: 1994 ( $\mathrm{N}=1037), 2001$ ( $\mathrm{N}=1093), 2009(\mathrm{~N}=1065)$ and 2012 $(\mathrm{N}=1034)$.

For the purpose of our analysis, educational rank was used as a proxy for socioeconomic position, as is done frequently in similar surveys $(16,18)$. Although people's socioeconomic position may be more accurately expressed by occupation or income, education lies at the heart of people's position in society because it is a fundamental determinant of both occupation and income. Education was recoded into two broad categories: lower education, encompassing primary school and vocational school, and higher education, encompassing secondary school or more. Using more than two categories was not possible. Due to the vast shifts in educational structure during the observed period, the analysis would not meet the statistical requirements for all the time points in this case (i.e. some categories would be too small). The relationship between gender, self-rated health and socio-economic position was determined by the Contingency Coefficient, a measure of association whose significance level is based on the chi-square statistics. A p-value of $\leq 0.05$ was considered significant in all the statistical tests. SPSS 19.0 for Windows (SPSS Inc., Chicago, IL) was used as a tool for analysis. 


\section{RESULTS}

\subsection{Self-rated health}

Figure 1 indicates that the entire 1981 - 2011 period was favourable in terms self-rated health. There was a steady upward trend, with the share of respondents reporting their health to be good or excellent growing from 14 percent in 1981 to 32 percent in 2011. A similar pattern can be observed for both genders, yet Slovenia is no exception to the rule that women are sicker but live longer. While official life expectancy figures show a continuous female advantage throughout this period, the share of women who report their health to be (very) good is 10 to 15 percent lower than the share of men. The difference is not extremely large, but remains statistically significant in all the time points (1981: $p<0.001 ; 1989: p<0.001 ; 1994: p<0.001 ; 2001: p<0.001$; 2011: $p<0.001$ ).

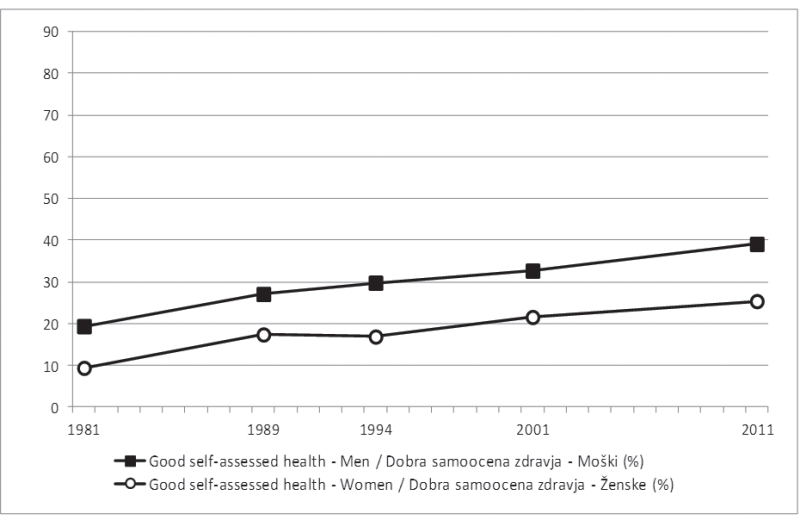

Figure 1. Percent of male and female respondents who rated their health as (very) good.

Slika 1. Odstotek anketirancev in anketirank, ki so ocenili svoje zdravje kot (zelo) dobro.

By adding education, which is our measure of social position, more interesting sub-trends emerge (Figure 2). Firstly, there are persistent gender differences in self-rated health in both educational groups, with lower and higher educated men consistently reporting better subjective health than women in the corresponding categories. The differences are statistically significant for both the higher and lower educated group in all the time points $(1981$ : $p<0.001 ; 1989$ : $p<0.001 ; 1994$ : $p<0.001 ; 2001: p<0.001 ; 2011: p<0.001)$. Secondly, there are considerable class differences within both genders along the educational divide. During the entire period, men with a higher education report significantly larger shares of good health than men with a lower education and the difference is even bigger for women. The differences for both men and women are statistically significant in all the time points (1981: $p<0.001 ; 1989: p<0.001 ; 1994: p<0.001 ; 2001: p<0.001$; 2011: $p<0.001$ ). While the male-female gap remains at around 10 percent and seems fairly stable over time, the educational gap within genders ranges between 25 and 30 percent and has increased markedly during the last thirty years. Finally, the overall picture gives a fairly robust and stable 'ranking' of groups according to self-rated health, when both gender and education are taken into account: lower educated women are at the bottom with the smallest share of self-rated good health, followed by lower educated men and higher educated women. At the top are higher educated men.

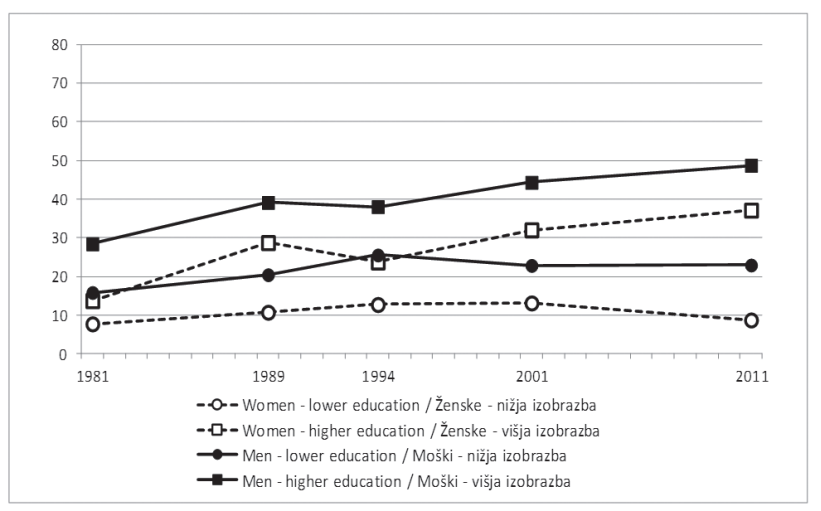

Figure 2. Percent of respondents who rated their health as (very) good by gender and education.

Slika 2. Odstotek anketirancev in anketirank, ki so ocenili svoje zdravje kot (zelo) dobro, po spolu in izobrazbi.

In addition to exposing continuous socio-economic differences within both genders, our cohort level analysis corroborates previously reported findings that class differences in health persist throughout life (Figure 3). Class differences along educational lines are quite pronounced in the female group and are statistically significant in all the time points (1981: $p<0.001 ; 1994$ : $p=0.021 ; 2007: p=0.016)$. They are also consistently present in the male group, and statistically significant in two time points (1981: $p=0.002 ; 1994: p<0.001 ; 2007$ : $\mathrm{p}=0.292)$. On the other hand, gender differences within educational groups are also present, but are weaker and become non-significant in the later life stages. The $p$-values for the lower educated group (1981: $p<0.001$; 1994: $p=0.324 ; 2007: p=0.126)$. The $p$-values for the higher educated group (1981: $p=0.008 ; 1994: p=0.115$; 2007: $p=0.861$ ). 
Interestingly, the shares of good heath for the two male groups are lower after 25 years and the gap along the educational line remains fairly stable. For women though, the share of respondents with good self-rated health has actually grown in the higher educated category, while it remains very low in the lower educated group. In other words, the difference among women in the same cohort has grown markedly over time. Higher educated women fared better than any other group and managed to 'catch up' with higher educated men after 25 years, reaching a very similar share of good self-rated health.

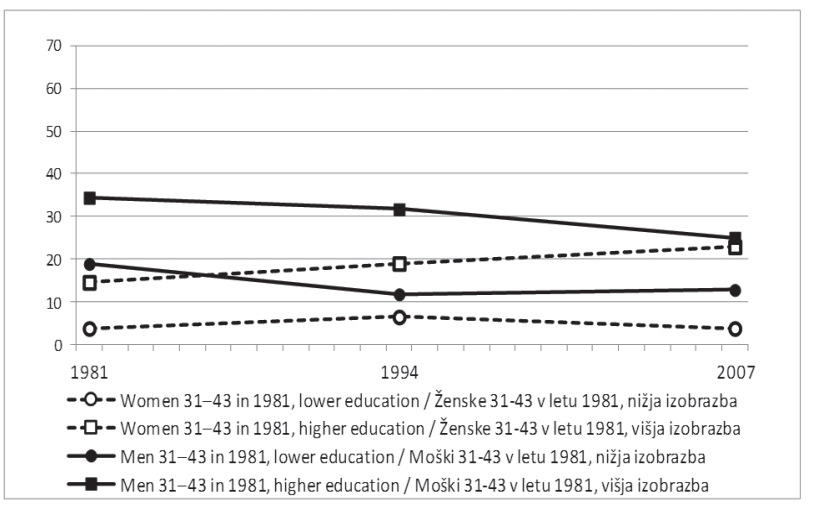

Figure 3. The percent of respondents who rated their health as (very) good by gender and education - cohort trend.

Slika 3. Odstotek anketirancev in anketirank, ki so ocenili svoje zdravje kot (zelo) dobro, po spolu in izobrazbi - trend kohorte.

\subsection{Indicators of psychological stress}

The four measurements date from between 1994 and 2012. During this period, between 30 and 40 percent of all respondents did not experience any of the three stress symptoms (insomnia, irregular heartbeat, anxiety) on a regular basis. In all the years, the shares of non-stressed respondents were larger in the higher educated group (between 36 and 47 percent) than in the lower educated group (between 27 and 36 percent). There are marked gender differences, with shares of non-stressed respondents ranging between 25 and 34 percent for women, and between 38 and 48 percent for men. Conversely, in all the years, women and the less educated were considerably more likely to report symptoms of stress. Two or three symptoms were regularly experienced by 26 to 32 percent of respondents in the higher educated group, compared to 35 to 46 percent in the lower educated group. They were reported by 21 to 33 percent of men, compared to 37 to 46 percent of women.
This again singles out the group of less educated women as the most vulnerable out of the four observed groups. To control for the effect of age and focus on the working period of life when dual-role strain is most pronounced, we observed the prevalence of stress symptoms in the population aged between 31 and 60 years only, which is roughly the working part of an average individual's life (Figure 4). The chart shows that men with a higher education are consistently the least stressed group, followed by men with a lower education and women with a higher education. The most stressed group are women with a lower education, with much larger proportions of them experiencing 2 or 3 stress symptoms on a regular basis. In all three measurements, there is a larger share of good self-rated health in the better educated category for both genders, yet statistically class differences along educational lines are non-significant for men (1994: $p=0.873 ; 2001$ : $p=0.226$; 2009: $p=0.280 ; 2012: p=0.075)$. They are, however, significant for women, with the exception of the last measurement (1994: $p=0.019 ; 2001: p=0.048$; 2009: $p<0.001 ; 2012: p=0.132)$. Gender differences are quite pronounced in the lower educated group where they are statistically significant in three out of the four time points (1994: $p=0.018 ; 2001: p=0.022 ; 2009$ : $p<0.001 ; 2012: p=0.151)$. In the higher educated group, they are less pronounced and are significant in the years $2009(p=0.007)$ and $2012(p=0.027)$ but not in the years $1994(p=0.959)$ and $2001(p=0.107)$. Nevertheless, women consistently report more symptoms and the gap seems to be growing with time.

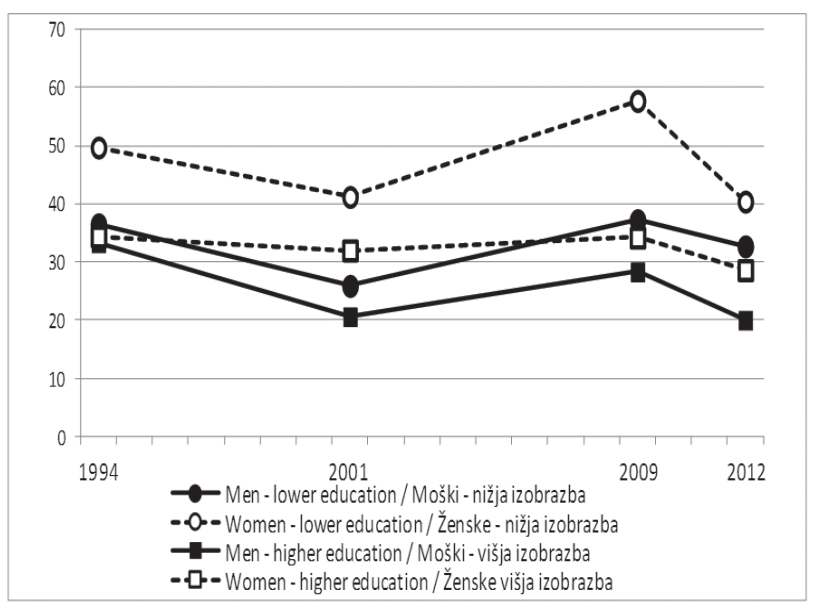

Figure 4. The percent of respondents aged 31 - 60 who regularly experience 2 or 3 symptoms of stress.

Slika 4. Odstotki anketirancev starih $31-60$ let, pri katerih so redno prisotni 2 do 3 simptomi stresa. 
Finally, to characterize the Slovenian normative environment as one of the structural elements determining national health care policy, we examined one of the longitudinal indicators of general population attitudes associated with the health care system (Figure $5)$. In all seven measurements, the vast majority of respondents (between 64 and 85 percent) agreed that the government should be fully responsible for providing health care for the sick. The share of those who believe the government should be partly responsible ranges between 14 and 33 percent, while the share of those who believe that providing health care is not the government's responsibility at all is negligible.

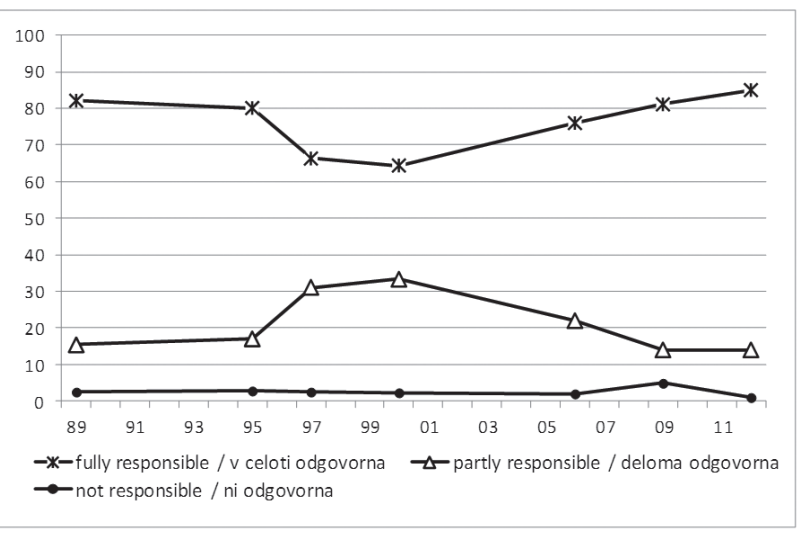

Figure 5. Attitudes towards the role of government in providing health care for all.

Slika 5. Stališča do vloge države pri zagotavljanju zdravstvenega varstva za vse.

\section{DISCUSSION}

Slovenia, like many Eastern European countries, has undergone the process of social and economic transition and happens to be one of the few countries where empirical indicators of self-assessed health are available for an extended historical period. The first two measurement waves date back into the socialist era, the third wave was carried out in the middle of the nineties when transition-related social stresses reached their peak, the fourth and fifth are from the period of social stabilization and economic prosperity after the year 2000, while the last wave was fielded when the global economic downturn that began in 2008 was well under way.

The 30 year trend is consistent with a large body of studies finding that women report poorer self-rated health than men. The results indicate that there was no dip in subjective health figures during the nineties, and no evidence that either men or women were more affected by the process of transition, which was, in terms of the wellbeing of the population, rather less turbulent in Slovenia than in some other eastern European countries. In Slovenia too, the gender gap was observed in both the social classes we constructed, but was more pronounced for women in the lower educated category. The association between social class and self-assessed health in Slovenia has been explored by several other studies in the last decade and they also found that a lower self-assessed social class reports poor self-rated health most often and should therefore comprise the focus of multisectoral interventions (22). Other socially and policy relevant factors associated with poor self-reported health were found to be marital status, employment status, subjective social class and region (23).

The second set of indicators was used primarily to examine the extent that dual role strain results in chronic tiredness and exhaustion in women, lowering their quality of life. The results seem in agreement with this assumption, as well as the assumptions about class differences in coping resources. The higher prevalence of stress symptoms among women supports the theory of chronic exhaustion resulting from the dual-role strain. The key source of strain seems to be work and issues of material well-being, not private life. Another study found that in Slovenia, for women, the independent contribution of socioeconomic position to depression is tenfold the contribution of the family situation. Similarly, in most of Eastern European countries, the depressive levels in both men and women are more strongly associated with socioeconomic position than family life (20). In Slovenia, a large proportion of women hold a full-time job, which was traditionally viewed as an asset. Yet the (lack of) influence over one's work situation and working hours has been shown to be a very significant factor in people's health, particularly for women. It is almost exclusively women who have both a stressful job and the primary responsibility for their home and children (11). Narrative-based research has identified two different and strongly gendered accounts of tiredness. In the first one, tiredness was defined as an irregular or minor event. In the second, most frequently reported by women, tiredness was defined as a severe, chronic and disabling condition described as 'total exhaustion'. Middle-aged women in particular described everyday life as a series of time-consuming situations, creating a vicious circle of constant exhaustion $(4,2)$. Flexibility of working hours is one way to alleviate the dual role tension, but the effects of such arrangements are controversial. In the short-term, increasing part-time work can help women 
reconcile job and family demands, but brings potential negative side effects such as worse working conditions and less opportunities for career development (12). The ageing population is another factor that is likely to add to dual-role strain by increasing the burden of caring for dependent family members. Since women will probably take on the bulk of responsibility for care that is no longer provided by the public sector, women's health will be at particular risk (11).

But if women are under more strain, lower class women are doubly so. Our results suggest that to a significant extent, socio-economic divisions in Slovenian are more decisive than the gender division, though both effects are present. As was pointed out by other scholars, similar circumstances may render both men and women vulnerable to ill health or good health. Equally, similar social circumstances may produce different effects upon the health of men and women (10). The protective effect of education comes as no surprise and was detected in numerous other surveys. As a rule, higher education leads to a better individual financial situation, a better career, a job with a lower risk of unemployment and, consequently, higher income, all of which facilitate access to health care and prevention, and reduce economic stress $(11,21)$. Our study found that differences in stress symptoms within the female group were much larger than in the male group, which again confirms that the protective effect of higher education seems to be particularly strong for women, giving them more opportunities to find jobs with good working conditions and relieve their dual-role strain. Slovenia, with its large proportion of employed women, is no exception here, but some authors suggest that the positive effect of education is largely temporary and limited to the first generation of well-educated women in Slovenia (19). During the last 30 years, the share of higher educated respondents and the share of respondents reporting good health grew steadily in both gender groups, suggesting the existence of a structural association between the two. As in many other countries (9), women in Slovenia have significantly increased their educational capital since 1980, and actually 'overtook' men in this respect. In 2012, 90 percent of the female respondents under 30 years of age had at least secondary education, compared to 66 percent of their male counterparts. With the exception of respondents aged 60 or more, where there is still a marked female educational disadvantage, women are now on average better educated than men. However, the share of men with good self-rated health remains larger. Higher education may lose its role as a tool for social promotion and status enhancement now that it has become widespread and more common for women than for men. Its competitive advantage in the labour market may diminish or even disappear, and with it the access to better jobs that it used to provide. It may still remain a source of self-satisfaction and cultural capital though.

We can expect the social and economic context to become harsher in the coming years, which with disproportionately affect groups with less coping capital and more structurally imposed strains, including women. A Swedish government survey found that women will be more vulnerable than men to the effects of societal and labour-market change. Finding work will be more difficult and unpaid work is likely to increase. Unemployment is likely to increase among the poorly educated as well as those trained for work in the public sector, primarily women. Large numbers of women are at risk of unemployment and a decline in their quality of life when the public sector downsizes and other sectors fail to pick up the slack (10). In other words, women feel less at ease with liberalization or the downscaling of the welfare state due to austerity policies currently offered as the necessary solution to reverse the economic decline in Slovenia.

Finally, there is a risk that the current economic crisis and the liberalization of social policies will result in a general enlargement of social inequalities. When class differences increase, poverty spreads more rapidly among women and children than men, as was indicated by other studies (11). A change in the social contract (transferring responsibilities from the public to the private sector) would affect everyone, but particularly people dependent on society's support. Accordingly, class, gender and ethnic differences in health are likely to increase. Based on historical survey evidence, we can expect that this development will again hit lower class or lower educated women more severely, causing an increase in overall stress, resulting in worse health in general and the generally reduced legitimacy of the social and political system. In Slovenia, collectivist attitudes toward public health care fully survived the period of transition and even seem to be strengthening after a small slump between 1995 and 2005. The norm that everyone should be entitled to accessible or free public health services is extremely strong. In addition, between 50 and 60 percent of respondent believe it is 'very unjust' if the wealthier are able to afford better health care, and only 10 percent say that such a system is at least partly just. These attitudes clearly suggest that individualistic or liberal policy solutions in the domain of health care are largely alien to the Slovenian public, which is something to be expected after several post- 
war generations were raised within the social, political and normative context of a comprehensive public health care system. Dismantling its vital components would doubtlessly cause public dissatisfaction and probably reverse some of the favourable health trends observed in the last 30 years.

This is why the most important message concerning the issue of women's health in Slovenia and elsewhere in times of economic downturn is the vital role of welfare and health policies. Welfare states are important determinants of health and health inequalities as they mediate the extent and impact of socioeconomic position on health (16). As UK scholars point out, their country's case is particularly instructive because of the process of polarization that occurred during two decades when inequality was off the political agenda from 1979 to 1997 . The result was a free market approach to economic, social and fiscal policy in which inequalities resulting from labour market restructuring and the emergence of new patterns of family life were magnified rather than moderated. As is confirmed by comparative research, national state policies play an important part in filtering the effects of social and socioeconomic change (13).

\section{CONCLUSION}

Perhaps the most striking finding from our longitudinal data was the stable growth of self-rated health in both genders and both educational groups despite major shifts in the political and economic system in the 1990s and despite the economic downturn after 2008. In our view, this is mainly due to the fact that in Slovenia, even after the end of the socialist era in 1991, a comprehensive welfare regime continued to function and no dramatic collapse of the social and health care system took place. Our individual-level analysis suggests that the welfare state was able to buffer the adverse effects of increased economic stresses to a significant extent, which resulted in favourable health outcomes for both genders.

Due to the global financial crisis and global economic competition, Slovenia now finds itself under pressure to revise its social contract and scale down social and health care systems, despite the fact that these universal arrangements were the building block of the favourable condition of women's and men's health in the past. Dismantling them may result in shortterm financial gain but is likely to trigger far-reaching negative consequences for public health, in particular in vulnerable groups. As in the past, social surveys will be a powerful instrument to monitor the development and alert policy makers of emerging health issues, but that is where their role ends.

\section{References}

1. Emslie $\mathrm{C}$, Hunt $\mathrm{K}$. The weaker sex? Exploring lay understandings of gender differences in life expectancy: a qualitative study. Soc Sci Med 2008; 67: 808-816.

2. García-Calvente M, Hidalgo-Ruzzante N, Del Río-Lozano M, Marcos-Marcos J, Martínez-Morante E, Maroto-Navarro G, Mateo-Rodríguez I, Gil-García E. Exhausted women, tough men: a qualitative study on gender differences in health, vulnerability and coping with illness in Spain. Sociol Health IIIn 2012; 34: 911-926.

3. Lahelma E, Arber S, Martikainen P, Rahkonen O, Silventoinen $\mathrm{K}$. The myth of gender differences in health: social structural determinants across adult ages in Britain and Finland. Curr Sociol 2001; 49: 31-54.

4. Popay J, Groves K. 'Narrative' in research on gender inequalities in health. In: Annandale E, Hunt K, editors. Gender inequalities in health. Buckingham: Open University Press, 2000: 64-89.

5. Pahor M, Novak-Antolič Ž, Zaletel-Kragelj, L. Stress burden in women in reproductive age in Slovenia - some causes and consequences. Zdrav Vestn 2009; 78: 281-288.

6. Carpenter M. Reinforcing the pillars: rethinking gender, social divisions and health. In: Annandale E, Hunt K, editors. Gender inequalities in health. Buckingham: Open University Press, 2000: 36-63.

7. Danielsson M, Lindberg G. Differences between men's and women's health: the old and the new gender paradox. In: Ostlin $P$, Danielsson M, Diderichsen F, Harenstam A, Lindberg G, editors. Gender inequalities in health: a Swedish perspective. Boston: Harvard Center for Population and Development Studies, 2001: 23-66.

8. Ferrarini $T$, Sjöberg $O$. Social policy and health: transition countries in a comparative perspective. Int J Soc Welfare 2010; 19: S60-S88.

9. Chenet L. Gender and socio-economic inequalities in mortality in central and eastern Europe. In: Annandale E, Hunt K, editors. Gender inequalities in health. Buckingham: Open University Press, 2000: 182-210.

10. Annandale E, Hunt K. Gender inequalities in health: research at the crossroads. In: Annandale E, Hunt K, editors. Gender inequalities in health. Buckingham: Open University Press, 2000: 1-35.

11. Harenstam A, Aronsson G, Hammarstrom A. The future of gender inequalities in health. In: Ostlin $P$, Danielsson M, Diderichsen $F$, Harenstam A, Lindberg G, editors. Gender inequalities in health: a Swedish perspective. Boston: Harvard Center for Population and Development Studies, 2001: 269-304.

12. Artazcoz L, Borrell C, Benach J. Gender inequalities in health among workers: the relation with family demands. Epidemiol Community Health 2001; 55 :639-647.

13. Graham H. Socio-economic change and inequalities in men and women's health in the UK. In: Annandale E, Hunt K, editors. Gender inequalities in health. Buckingham: Open University Press, 2000: 90-122.

14. Arber S, Cooper H. Gender and inequalities in health across the lifecourse. In: Annandale E, Hunt K, editors. Gender inequalities in health. Buckingham: Open University Press, 2000: 123-149.

15. Hafner-Fink M, Uhan S. Bipolarity and/or duality of social survey measurement scales and the question-order effect. Qual Quant 2011; 14: 839-852. 
16. Bambra C, Pope D, Swami V, Stanistreet D, Roskam A, Kunst A, Scott-Samuel A. Gender, health inequalities and welfare state regimes: a cross-national study of 13 European countries. J Epidemiol Community Health 2009; 63: 38-44.

17. Idler EL, Benyamini Y. Self-rated health and mortality: a review of twenty-seven community studies. J Health Soc Behav 1997; 38: 21-37.

18. Terje A, Eikemo T, Huisman M, Bambra C. Kunst A. Health inequalities according to educational level in different welfare regimes: a comparison of 23 European countries. Sociol Health IIIn 2008; 30: 565-582.

19. Kamin T, Berzelak N, Ule M. The influence of education on differences in depressive symptoms between men and women in Slovenia. Zdrav Varst 2011; 51: 33-42.
20. Van de Velde S, Levecque K. Gender differences in depression in 23 European countries: cross-national variation in the gender gap in depression. Soc Sci Med 2010; 71: 303-313.

21. Knesebeck O, Verde PE, Dragano N. Education and health in 22 European countries. Soc Sci Med 2006; 63: 1344-1351.

22. Farkaš-Lainščak J, Pahor M, Zaletel-Kragelj L. Self-rated health in different social classes of Slovenian adult population: nationwide cross-sectional study. Int J Public Health 2011; 56: 45-54.

23. Farkaš-Lainščak J, Zaletel-Kragelj L. Self-rated health in Slovenian adults. Slov Kardiol 2008; 5: 42-49. 